\title{
Science, Technology, Engineering, and Mathematics Integration: Science Teachers' Perceptions and Beliefs
}

\author{
Esra Açıkgül Fırat \\ Department of Science and Mathematics Education, Faculty of Education, Adiyaman University, Adiyaman
}

*Corresponding Author: eacikgul@adiyaman.edu.tr

\section{ABSTRACT}

The purpose of this study was to determine the science teachers' perceptions of and beliefs about integrated science, technology, engineering, and mathematics (STEM) education in the science curriculum. A case study research method was used to determine teachers' perceptions and beliefs of integrated STEM education in the science curriculum. The research was conducted with the participation of ten science teachers who worked in secondary schools located in different regions of Turkey. In this study, semi-structured interviews were conducted for data collection. The data obtained from the study were analyzed using content analysis. During the content analysis process, open and axial coding steps that are based on grounded coding were followed. According to the findings, teachers' perceptions of STEM education knowledge were examined under three categories: STEM education concept knowledge, curriculum knowledge, and STEM education implementation knowledge. In the study, it was determined that most of the teachers considered themselves inadequately prepared for integrated STEM education in the science curriculum. When teachers' beliefs regarding the problems that might be encountered during an integrated STEM education process were examined, it was found that the emphasis was especially on teacher-based problems. Furthermore, teachers believed that integrated STEM education would have positive effects on teachers, students, and science education.

KEY WORDS: science education; science, technology, engineering, and mathematics education; science teachers; teachers' perceptions; teachers' beliefs

\section{INTRODUCTION}

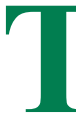
he science includes complex events in daily life. Therefore, in science teaching, students need to deal with complex problems and natural phenomena that cannot be easily understood or solved from a single discipline framework (You, 2017). Because in the real world, individuals do not evaluate the situations they face as disciplinary. For this reason, they benefit from interdisciplinary approaches that provide a holistic approach to events. Therefore, science, technology, engineering, and mathematics (STEM), which is an interdisciplinary discipline, has become very popular in science teaching in recent years. STEM is a commonly used abbreviation to indicate education or professional practice in the fields of STEM (McDonald, 2016). Moore et al. (2014) explained integrated STEM education as "an effort to combine some or all of the four disciplines of STEM into one class, unit, or lesson that is based on connections between the subjects and real-world problems" (p. 38). The science curriculum in Turkey, which was updated in 2013 by the Ministry of National Education (MoNE), included knowledge (living things and life, substance and change, physical instances, earth, and universe), skill (scientific process skills, and life skills), perception (behavior, motivation, values, and responsibility), and science, technology, society, environment learning fields. In this curriculum, the importance of science, technology, and society was emphasized, while integrated STEM education and engineering skills were not included (MoNE, 2013). In the next science curriculum, which was reviewed in 2018 and aims to raise all individuals as science-literate individuals, integrated STEM education was mentioned in one of the main goals as "providing basic knowledge about astronomy, biology, physics, chemistry, earth and environmental sciences, and science and engineering applications" (MoNE, 2017, p. 9). In this science curriculum, it is aimed for students to acquire "engineering and design skills" with integrated STEM education emphasis; these skills are clarified as follow:

Engineering and design skills: This field covers creating products with the acquired knowledge and skills and developing strategies to create added value to these products by enabling the integration of sciences with mathematics, technology, and engineering, and by bringing the students to a level, where they are able to make discoveries and innovations with an interdisciplinary perspective to the problems (MoNE, 2017, p. 9).

Within this context, the role of the teacher is to help students reach a place of higher-level thinking, where they can develop products and make innovations by guiding them through the integrated STEM education in their science classes. Reforms in the teaching of STEM disciplines especially have critical importance for Turkey's economic competitiveness; since 
innovation and efficiency of human capital are lower than other developed countries (Turkish Academy of Sciences, 2010). Thus, teachers play a significant role as students acquire these skills. Despite this role of the teachers, studies have determined that there are teacher-based problems in integrated STEM education (Clewell et al., 2005; Countryman and Olmsted, 2012). For this reason, STEM teachers in Pre-K-16 should change in terms of content and teaching (Lawrenz et al., 2017). Even though the benefits of a STEM education integrated curriculum are clear, there are teacher-related problems in the implementation of STEM Education (Ring et al., 2017). First, teachers should strongly believe that this education is the best for their students, for them to be committed to implementing the integrated STEM education (Ring et al., 2017 has Huntley, 1998). In his study, Lederman (1999) stated that there is consistency between teachers' beliefs and classroom applications since they piece their teaching decisions and intentions together and improve their skills that are necessary for transforming knowledge to application. One of the other problems that are encountered is the difficulties regarding integration due to the lack of knowledge about the meaning of STEM, where does it fall within the curriculum, and how to apply it. For this reason, in this study teachers' knowledge and beliefs regarding integrated STEM education in the science curriculum were investigated; since teachers' knowledge and beliefs affect the teaching applications (Thompson, 1992).

\section{LITERATURE REVIEW}

In recent years, there has been increasing importance attached to STEM education based on interdisciplinary approaches, which focus on real-world problems and projects within which concepts and skills are learned separately in each discipline (English, 2017). STEM education is the abbreviation of an approach that is as complicated as it is important (National Research Council, 2011). STEM education is considered as a supplementary approach for curriculum and instruction (Roberts, 2012). The concept of STEM Education was first used in 2001 by American Biologist Judith A. Ramaley, the director of The National Science Foundation (Fioriello, 2014). Ramaley defined STEM as education research within which learning is placed in a context; students solve real-world problems and have the opportunities to follow innovations (Daugherty, 2013). STEM education can be defined as an interdisciplinary approach, which provides real-life settings to individuals and addresses four independent disciplines in a common context. During STEM education, students can solve new problems and draw conclusions based on STEM from what they have previously learned (Roberts, 2012).

At present, STEM with its features is one of the priorities of education. To raise $21^{\text {st }}$ century citizens who are knowledgeable about STEM, many reforms have been made to the formal STEM education system and especially to science education (Dani et al., 2017). In this way, STEM education has been introduced to the curriculums of many countries. Politicians consider STEM literacy as important in terms of the individual welfare of every citizen and the competitive power of the country within the global economy (National Research Council, 2011). A population with a strong comprehension of STEM education is the key to a successful future and a lifelong effective STEM education is the mechanism to provide this strong comprehension (Lawrenz et al., 2017). This is the reason why countries advocate for this interdisciplinary approach, which is considered important for the progression of a country, in their curriculums. STEM education integration, as a tool for giving meaning to the education of the students through STEM disciplines, provides advantages such as its importance for dealing with real-world problems and increased use of multidisciplinary teams in many jobs (English, 2017).

In many STEM-based curriculums, interdisciplinary projects are used, to help students to see the connections between the disciplines by longitudinal participation of students to the tasks that require authentic problem solving and implementation (Lesseig et al., 2017). With the use of these projects, STEM education instills creative problem-solving techniques and enables the development of future innovations (Roberts, 2012). Thus, countries are aiming for increasing their success by raising individuals with strong STEM comprehension. In the National Research Council (2011) report in America, it was stated that the aim of STEM education is to be advanced in STEM disciplines and prepare students for technical careers, to improve science literacy of all students, to help all students prepare for university, and to equip the future workforce for individual development and national welfare.

STEM projects, being interdisciplinary and open-ended, usually make the implementation more difficult (Lesseig et al., 2017). Thus, STEM education is considered to be a complicated process. Because of this complication and uncertainty, STEM projects develop multiple intelligences and skills of the students (Lesseig et al., 2017). To practice an effective STEM education process and to have students with these skills, it is important to have effective school improvement, to encourage curriculum implementation, and to have access to qualified teachers and school leaders (English, 2017). Teachers, who are responsible for creating a STEM environment and carrying out the implementation, play a significant role in STEM education. System politics and resources shape the context that the teachers are working within but it is the teachers themselves who have the potential to execute reforms by developing their teaching practices meticulously and consistently (Galosy and Gillespie, 2013).

Due to this reason, there is a need for teachers, who understand the importance of STEM fields with their contents, to STEM programs to succeed (Epstein and Miller, 2011). This complicated process starts when teachers realize their students' conceptual development regarding STEM, questioning processes, and connections with the real world; and continue as they manage the education for further improving the students learning skills (Allen et al., 2016). Thus, the main goal of STEM initiatives is to increase the number and the quality of STEM teachers. In this way, better-equipped teachers can help 
more students to improve their $21^{\text {st }}$-century skills and capacity to be innovative (Corlu et al., 2014).

The socio-cultural and political-economic urgency based on the advancement of STEM teachers shows the complexity of the professional learning of a STEM teacher within vocational development interferences (Fore et al., 2015). Despite the importance of teachers' role in this process, teachers' effect on a primary school level is mostly ignored in interest and career research (Kim et al., 2015). There are studies stating that teacher-centered problems exist in the process of STEM education (Cavlazoglu and Stuessy, 2017; Daugherty et al., 2014; Hutchison, 2012; Siew et al., 2015). Hutchison (2012) noted the lack of certified and qualified teachers for STEM education at American Secondary Schools and Colleges. On the other hand, Cavlazoglu and Stuessy (2017) mentioned that having teachers' expertise in a single discipline creates problems in STEM education. And unfortunately, most teachers are not trained for integrating related STEM subjects in the curriculum (Daugherty et al., 2014). Teachers need to have a command of all STEM subjects to realize STEM integration. Thus, during the implementation process of STEM education, primarily, the teachers should be equipped with STEM content knowledge (Kim et al., 2015). There is evidence that teachers content knowledge foresees students' accomplishments (Goldhaber et al., 2016). It is thus considered a necessity for teachers to have adequate field knowledge to teach the subject well (Kahan et al., 2003).

Teachers' knowledge is not considered as an isolated construct from in-class behaviors of the teachers and their effects on the students (Fennema and Franke, 1992). For this reason, teachers are expected to have pedagogic field knowledge in addition to content knowledge, for them to manage the education process successfully. According to Schulman, teaching begins with the teachers knowledge and teachers thoughts about the way this knowledge is conveyed to the students (Shulman, 1987). Thus, an introduction to teachers' vocational development based on field knowledge and pedagogic strategies (pedagogic field knowledge) for teaching STEM discipline is required, for the teachers to feel comfortable with integrating STEM education into their classes (Cunningham et al., 2007). A strong STEM pedagogic field knowledge provides the teachers with the ability to recognize and measure the conceptual development of their students regarding STEM, their questioning processes and the real world connections, for them to intentionally change their teaching in a productive manner (Allen et al., 2016). Studies in the literature show that teachers can explain the interdisciplinary nature of STEM (Bakırc1 and Kutlu, 2018; English, 2017; Eroğlu and Bektaş, 2016; Lesseig et al., 2017; Roberts, 2012; Uğraş, 2017). However, teachers are experiencing problems during STEM education due to the lack of STEM training (Daugherty et al., 2014; Siew et al., 2015; Uğraş, 2017). In addition, there are studies that indicate that teachers are experiencing these problems in terms of time and equipment (Bakırcı and Kutlu, 2018; Bölükbaşı and
Görgülü, 2019; Eroğlu and Bektaş, 2016; İnançlı and Timur, 2018; Özcan and Koştur, 2018; Straw et al., 2012).

Furthermore, studies showed that teachers' beliefs, in addition to their knowledge, have effects on their teaching practices (Richardson et al., 1991; Staub and Stern, 2002; Thompson, 1992; Zeldin et al., 2008). Since teachers' beliefs affect the STEM integration process, it is considered important to determine their beliefs regarding the implementation of STEM. A belief regarding STEM might be attached to a behavior or a consequence of a behavior. Belief might also be attached to someone else's approval or refusal (Pryor et al., 2016). Thus, it is believed that teachers' STEM knowledge and beliefs would shape the STEM implementations in the curriculum. Thompson (1992) also stated that teachers' knowledge and beliefs significantly affect the way they interpret and implement the curriculum. The aim of the research was to determine the science teachers' perceptions of and beliefs about integrated STEM education into the science curriculum. For this purpose, the answers to the following questions were sought:

1. What are science teachers' perceptions of their STEM education knowledge?

2. What extent do teachers perceive themselves as being able to integrated STEM education?

3. How are science teachers' beliefs regarding integrated STEM education?

4. What are the science teachers' suggestions regarding integrated STEM education?

\section{METHODS}

In the study, the case study research method was used to determine teachers' perceptions of and beliefs regarding integrated STEM education (Yin, 2014). A case study is both the investigation process of the issue and the results of this investigation, and it ensures reliability by profoundly diversifying explanations and interpretations not in one step but rather throughout the whole research process (Denzin and Lincoln, 2005). The reason behind choosing a case study in this study was the fact that the case study is an empirical study that examines the contemporary phenomenon in real-life contexts (Yin, 2014). The case of this study was science teachers, who will be the practitioner of a new science curriculum. Since the teachers who were the practitioners of the curriculum were examined in real-life contexts, a case study was used in this study.

\section{Participants}

The research was conducted with the participation of ten science teachers, who work in different cities. It is considered appropriate to carry out case studies with enough people to determine the themes of cases and to make cross-case theme analyses (Creswell, 2007). In qualitative studies, it is possible that participants are intentionally selected, and purposeful sampling technique was used to select participants for this study (Yin, 2014). Purposeful sampling enables deep and detailed examination of cases that are rich in terms of information 
(Patton, 1999). Science teachers were selected, since they were the ones, who would implement the science curriculum. The participants had similar educational backgrounds. The different regions of Turkey were also taken into account when selecting the participants. In Turkey, teachers from around the country came together and participate in in-service training seminars. The content and nature of this study were shared with the science teachers who participated in one of these seminars and volunteers were asked to participate in the study. Researchers held interviews during the seminar to make it more economical to conduct this research. Interviews with the volunteer teachers continued until the data gathered were similar and no new information was received from the new participant (Merriam, 1998), and thus the data saturation was reached (Corbin and Strauss, 1990). At the point of data saturation, the sample size consisted of ten participants. All of the participants graduated from a Faculty of Education Department of Elementary Science Education. Furthermore, one of the teachers had a master's degree and one a doctoral degree; all other teachers had bachelor's degrees. The characteristics of the participants and the school environments they work in are summarized below:

T1: He is working in Malatya. He has 4 years of teaching experience. The school he is working with offers fulltime education. There are 25-30 students in each class in the school. The school has facilities such as smart boards in the classrooms as well as science and computer laboratories.

T2: He is working in Adiyaman. He has 3 years of teaching experience. There are 25-30 students in each class in the school. There are smart boards in the classrooms but there are no science and computer laboratories in the school.

T3: He is working in Şırnak. He has 7 years of teaching experience. The school he is working at provides halfday education. There are 40-50 students in each class in the school. There are no smart boards nor science and computer laboratories in the school.

T4: She is working in Gaziantep. She has 8 years of teaching experience. She has a master's degree. The school she is working at provides full-time education. There are on average 30 students in each class in the school. There are smart boards, as well as science and computer laboratories in the school.

T5: She is working in Malatya. She has 10 years of teaching experience. She has a postgraduate degree at a doctoral level. The school she is working in provides full-time education. There are on average 20 students in each class in the school. There are smart boards, as well as science and computer laboratories in the school.

T6: She is working in Nevşehir. She has 1 year of teaching experience. The school she is working at provides fulltime education. There are 7-12 students in each class in the school. There are smart boards, as well as science and computer laboratories in the school.

T7: He is working in Şırnak. He has 1 year of teaching experience. The school he is working at provides halfday education. There are 30-40 students in each class in the school. There are no smart boards nor science and computer laboratories in the school.

T8: She is working in Malatya. She has 2 years of teaching experience. The school she is working at provides halfday education. There are 25-30 students in each class in the school. There are science and computer laboratories in the school but there are no smart boards in the classrooms.

T9: He is working in Adiyaman. He has 2 years of teaching experience. The school he is working at provides full-time education. There are 15-20 students in each class in the school. There are smart boards in the classrooms but there is no science laboratory in the school.

T10: She is working in Denizli. She has 9 years of teaching experience. The school she is working at provides fulltime education. There are 25-30 students in each class. There are smart boards, as well as science and computer laboratories in the school.

\section{Instrument and Procedures}

In this study, interviews were conducted for data collection. The questions were semi-structured and open-ended. Interviews were audio-taped. During the data collection process, the first interview protocols were prepared (Creswell, 2009). The protocols were prepared to contribute to the reliability of the study. In these protocols, there were 11 open-ended questions about the science teacher's perceptions of and beliefs regarding integrated STEM education in the science curriculum. The protocol was finalized after expert opinions were received and the necessary adjustments were made. The experts were two science education experts, a curriculum development expert and a language expert. Open-ended questions for the implementation of the current program have been removed in response to the experts' recommendations. In addition, necessary corrections have been made since some of the questions were not clear. Interviews started with questions such as "Have you ever heard of STEM before?." The examples regarding the open-ended questions in the protocol are provided in Table 1.

\section{Table 1: Examples of semi-structured interview questions}

\begin{tabular}{|c|c|}
\hline Sub problem & Semi-structured interview questions \\
\hline $\begin{array}{l}\text { What are science teachers' } \\
\text { perceptions of their STEM }\end{array}$ & $\begin{array}{l}\text { What does the concept of STEM mean } \\
\text { to you? }\end{array}$ \\
\hline Education knowledge? & $\begin{array}{l}\text { Are you informed about the revisions in } \\
\text { the science curriculum? What kinds of } \\
\text { revisions were made? }\end{array}$ \\
\hline $\begin{array}{l}\text { What extent do teachers } \\
\text { perceive themselves as being }\end{array}$ & $\begin{array}{l}\text { Do you consider yourself qualified for } \\
\text { integrated STEM education? }\end{array}$ \\
\hline
\end{tabular}

able to STEM education?

How are science teachers' How do you think STEM integrations beliefs regarding integrated affect science education?

STEM education?

What are the science How should STEM education be teachers' suggestions integrated into science classes? regarding integrated STEM How should STEM laboratories be education? designed?

How should teachers' competency regarding STEM education be ensured?

STEM: Science, technology, engineering, and mathematics 
A pilot study was conducted after the protocol was prepared. A pilot study helps to reorganize the data collection plans in terms of data content and also the procedures that are followed (Yin, 2014). In response to the pilot study, questions were altered - if necessary - by determining potential problems and an average interview duration was planned. For example, "STEM education" was used instead of "STEM integration" in open-ended questions before the pilot study. It was changed to integrated STEM education because it was determined that the teachers perceived the entire science course as STEM applications in the pilot study. Conducted interviews were recorded by tape recorder and note-taking techniques. After the interviews were concluded, audio records were transcribed. In addition, the Turkish Science Education Curriculum (MoNE, 2013) that was reviewed in 2018 was examined by document analysis technique and the data regarding STEM integration are provided in the findings section.

\section{Trustworthiness and Transferability}

To ensure the trustworthiness and transferability of the study, the research method of the study, participants, data collection, and analysis process were represented. Furthermore, by performing open coding during the data analysis process, pattern matching was made, the explanations of these matchings and opposed explanations were addressed. By questioning and constantly comparing open coding, the researchers were able to overcome subjectivity and prejudice (Corbin and Strauss, 1990). Hence, it can be said that avoiding bias, research reflects reality. To provide data reliability, recordings and their analysis were examined and readjusted if necessary by another researcher.

Member checking was also used in the study, to provide credibility. Creswell and Creswell (2002) suggested member checking, which is used to ensure data accuracy by returning the final report, certain explanations or themes to the participants, and receiving feedback about the accuracy of the findings. For this purpose, two randomly selected participants (T6 and T8) were given the findings of the study and asked to write a report by evaluating the accuracy of the findings for reflecting their situation and whether the results are related to their responses or not. The reports are as follow:

T6: Examining the findings regarding each subproblem of the research, obtained themes are in line with the answers I provided for research questions. In the interview, concerning the first sub-problem that examines the knowledge of the participants regarding integrated STEM education, I mentioned that STEM is an interdisciplinary approach and it produces process driven products by discussing STEM interrelatedly. It is also true that I expressed my opinion about simplifying the attainments and making rearrangements. In addition, the fact that experiments or projects are not integrated into daily life and neglect of lifelong learning reflects our situation in terms of considering STEM laboratories as classical science laboratories. Regarding the second sub-problem of the research, the findings about financial and time problems are also consistent with my statements.
I believe STEM would contribute to students science learning, which is also coherent with the research findings. About the third sub-problem of the research, which is how the STEM trainings would be provided, I mentioned that these trainings should be provided where teachers can actively participate. This was thematized in the research as training through experience. This study reflects the situation in our country. I wish you success. T8: STEM knowledge: This study shows that teachers are aware of integrated STEM education but they do not have knowledge about the contents of it. The applications of national education also indicate this situation. This supports the findings of the study regarding teachers having insufficient knowledge. Even though teachers have theoretical knowledge about the contents of STEM or how it plays a part in the curriculum, there are still setbacks in practice, which also supports the findings of the study. Beliefs regarding integrated STEM education: Teachers, who are qualified in STEM education, would also be highly sufficient in implementing this education to their fields. Implementations of integrated STEM education: Since teachers are not provided with sufficient knowledge about this subject, they do not actually know what to do. What needs to be done about this situation is to provide applied STEM trainings for teachers. In the study, there are findings in this direction. After that schools should be reconstructed in accordance with these implementations. This way by implementing STEM, individuals with desired qualifications would be raised.

Examining the reports from T6 and T8, it can be claimed that the findings of this study reflect the real-life situations of the teachers. This contributes to the plausibility of the study.

\section{Data Analysis}

The data obtained from the study were analyzed using content analysis. The main purpose of the content analysis is to reach the concepts and relationships that can explain the collected data and interpret them in an understandable way (Yildırım and Şimşek, 2011). During the content analysis process, open and axial coding steps that are based on grounded coding were followed (Corbin and Strauss, 1990). In open coding, to reveal the similarities and differences, events/actions/interactions are compared with others and conceptually similar situations are grouped together for creating categories and sub-categories (Corbin and Strauss, 1990). In open coding, the researcher produces categories and their features and aims to determine how the categories dimensionally change (Strauss and Corbin, 1998). Thus, in the first round of the coding, two researchers tried to produce the codes by analyzing line by line. In addition, the data were coded by two researchers, and the agreement between coders was calculated. Agreement between coders is reached by two or more coders agree on codes that are used in the same text (Creswell, 2009). During the analyses, more than $90 \%$ agreement between researchers was reached. In the second round consistency and importance of each code, the corrections that were made for the codes were discussed; the coding researchers made were compared and for the codes with 
a difference of opinion, compromises were reached. During the analysis, process codes were tried to be determined by fixed comparative analysis methods (Corbin and Strauss, 2015). In the axial coding method, the coding process takes place around the axis of a category, and the categories are related to each other at the level of features and dimensions (Strauss and Corbin, 1998). The codes produced during the third round of analysis brought together and correlated during axial coding and categories were formed. The analysis process ended when there were no more new data or coding left. An example for codes produced during open coding, categories and themes formed during selective coding are as follow:

T3: I do not think that teachers have a sufficient level of preparedness about integrated STEM education. There are many older teachers and I do not think that they can adapt to these applications.

- Theme: Problems with integrated STEM education

- Category: Teacher-based problems

- Codes: problem, teacher, age of teacher.

\section{FINDINGS}

The data obtained in the study were examined through three research questions. In this section, findings obtained from the analysis of the data are presented.

\section{Findings of the Analysis of the First Research Question}

For the first research question, science teachers' perceptions of their STEM education knowledge were examined. In line with the analysis of the obtained data, teachers' perceptions of STEM education knowledge were examined under categories of STEM concept knowledge, curriculum knowledge, and implementation knowledge (Table 2).

Table 2 shows that teachers' perceptions of STEM concept knowledge were addressed as adequate and inadequate knowledge. Statements of the teachers, who had the perception of sufficient information about the concept of STEM, indicated that teachers identify STEM as an interdisciplinary approach, that they had knowledge about which fields were included in STEM and that they mentioned the integration of these fields to each other. It was also determined that they considered STEM as a process of producing a product using engineering skills. For example, T6 represents STEM as the transformation of what's inside a student's mind into a project and also explained it as producing a product using engineering and mathematics. Some teachers (T10, T3, T4, T7, and T9) could not explain the concept of STEM in a sufficient way. These teachers, even though they have heard of STEM, do not know what it means. T9 explained STEM as:

I have heard the name STEM, I guess in a meeting that was organized by district directorate of national education. They will include it to the new curriculum.

But I do not know the contents of it.

When teachers' perceptions of knowledge regarding the changing curriculum were examined, it was determined that most of them were aware of the inclusion of integrated
STEM knowledge into the new curriculum. In Figure 1, teachers' curriculum knowledge was examined in correlation with adequate and inadequate STEM concept knowledge of teachers.

Teachers with adequate STEM concept knowledge were more aware of the changes in the curriculum. Examining teachers' perceptions of their knowledge about the changes regarding objectives in the new curriculum, it was determined that teachers with adequate STEM concept knowledge had more information about the content, order, and simplification of the objectives. Figure 1 shows that teachers with both adequate and inadequate STEM concept knowledge were aware of STEM integration. This indicates that teachers' knowledge regarding STEM education was hearsay. When teachers' STEM implementation knowledge was examined using their statements regarding STEM laboratories, the situation became clearer because some teachers made no statement and most of them had inadequate knowledge about the implementation. For example, T5, who was aware that STEM education was included in the curriculum and made satisfactory explanations about the concept of STEM, mentioned about conducting experiments, equipment shortage, and time limitations. This

\begin{tabular}{llc}
\hline $\begin{array}{l}\text { Table 2: Teachers' perceptions of STEM education } \\
\text { knowledge }\end{array}$ & \\
\hline Categories & Codes & Participants \\
\hline STEM & Adequate knowledge & $\mathrm{T} 1, \mathrm{~T} 2, \mathrm{~T} 5, \mathrm{~T} 6, \mathrm{~T} 8$ \\
concept & Inadequate knowledge & T10, T3, T4, T7, T9 \\
knowledge & & \\
Curriculum & Learning objectives & $\mathrm{T} 2, \mathrm{~T} 4, \mathrm{~T} 5$ \\
knowledge & Content of objectives & $\mathrm{T} 1, \mathrm{~T} 4, \mathrm{~T} 6, \mathrm{~T} 8$ \\
& Order of objectives & $\mathrm{T} 1, \mathrm{~T} 5, \mathrm{~T} 6, \mathrm{~T} 8$ \\
& Simplification of objectives & $\mathrm{T} 10, \mathrm{~T} 3, \mathrm{~T} 2, \mathrm{~T} 4, \mathrm{~T} 5, \mathrm{~T} 6, \mathrm{~T} 8$ \\
& STEM & $\mathrm{T} 5, \mathrm{~T} 10$ \\
& Learning skills & $\mathrm{T} 1, \mathrm{~T} 4, \mathrm{~T} 5, \mathrm{~T} 7, \mathrm{~T} 8, \mathrm{~T} 9, \mathrm{~T} 10$ \\
\hline \multicolumn{2}{l}{ STEM implementation knowledge }
\end{tabular}

STEM: Science, technology, engineering, and mathematics

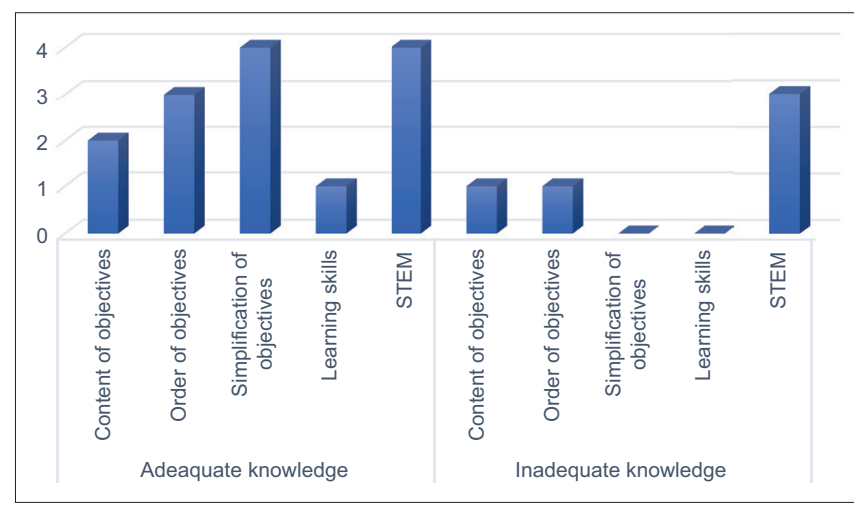

Figure 1: Teachers' perceptions of curriculum knowledge in correlation with their science, technology, engineering, and mathematics concept knowledge 
indicated that T5 saw STEM laboratories as regular science laboratories. Furthermore, it can be seen that T5 was not aware of life-long learning skills that were added to the curriculum. It was also determined that other teachers perceive STEM laboratories as science laboratories, where teachers conducted demonstration experiments in crowded classrooms.

Findings of the Analysis of the Second Research Question The second research question determined how teachers perceived themselves as being able integrated STEM education (Table 3).

When Table 3 is examined, it can be seen that many teachers considered themselves inadequate on integrated STEM education. Teachers' statements show that teachers, who considered themselves adequate, mostly relied on their experiences. For example, T6 believed that she was prepared for providing integrated STEM education and expressed this as follows:

I consider myself qualified about STEM integration. We can gain more experience about projects and experiments. I do not think that we are totally far from subject.

The statement of T6 shows that she would implement STEM education based on the previous experiences. Figure 2 shows the comparison of teachers, who considered themselves

\begin{tabular}{|c|c|c|}
\hline \multicolumn{3}{|c|}{$\begin{array}{l}\text { Table 3: Teachers' perceptions of their integrated STEM } \\
\text { education }\end{array}$} \\
\hline Categories & Codes & Participants \\
\hline \multirow[t]{2}{*}{ Perceived self-efficacy } & Adequate & $\mathrm{T} 4, \mathrm{~T} 5, \mathrm{~T} 6, \mathrm{~T} 7$ \\
\hline & Inadequate & $\mathrm{T} 1, \mathrm{~T} 10, \mathrm{~T} 2, \mathrm{~T} 3, \mathrm{~T} 8, \mathrm{~T} 9$ \\
\hline
\end{tabular}

adequately prepared for integrated STEM education and who had adequate STEM knowledge.

When Figure 2 is examined, a relationship between beliefs regarding self-efficacy and knowledge was only found for participants $\mathrm{T} 5$ and $\mathrm{T} 6$. The reason for teachers with adequate knowledge to feel unqualified might be the lack of information about the implementation of integrated STEM education. Teachers who considered themselves inadequate also stated that they did not receive any training about STEM, and they felt unqualified since this was a new requirement. Their statements also supported this situation. However, teachers felt confused about the way integrated STEM education into the science classes would be implemented.

Findings of the Analysis of the Third Research Question In the third research question, teachers' beliefs about integrated STEM education were determined. As a result of the obtained data, three categories were formed; the potential problems that could be encountered during the implementation of integrated STEM education and the effects of integrated STEM education. Table 4 introduces the categories and codes, which were formed regarding teachers' beliefs about integrated STEM education.

When teachers' beliefs about potential problems regarding integrated STEM education were questioned, they stated that there might be problems stemming from themselves. What draws attention here is that teachers, who considered themselves adequately prepared for integrated STEM education, also talked about potential problems caused by teachers. Furthermore, when teachers' beliefs regarding potential problems in integrated STEM education were examined in terms of their STEM knowledge. Figure 3 was obtained.

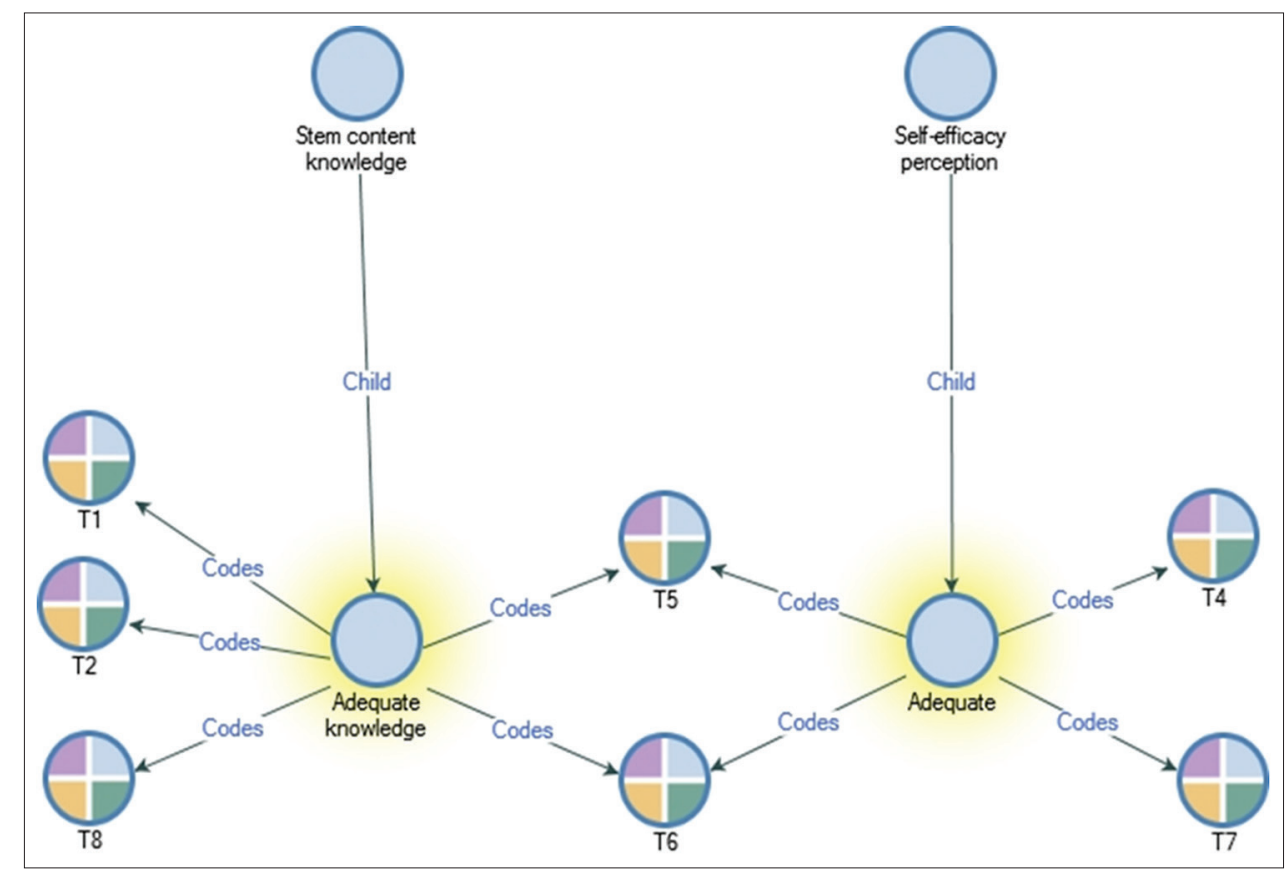

Figure 2: The comparison of teachers who consider themselves adequately prepared for science, technology, engineering, and mathematics (STEM) integration and STEM knowledge 
When Figure 3 is examined, it can be seen that teachers with and without adequate knowledge talked about an equal number of teacher-based problems. Figure 3 shows that teachers with adequate STEM education knowledge believed that more problems might be faced. In addition to the teacher-based problems, teachers also stated that there might be practicality, economic, and timing problems. It is noteworthy that only teachers with inadequate STEM education knowledge talked about problems regarding time.

In addition to the problems that might be encountered, teachers also mentioned the effects of integrated STEM education. The data show that teachers believed that integrated STEM education would have effects on science education, education system, teachers, and students. Teachers believed that integrated STEM education would have positive effects on teachers' career and personal development. For example, T4 stated that:

It would majorly contribute to career development. Because every year technology changes, develops,

\section{Table 4: Beliefs about integrated STEM education}

\begin{tabular}{llc}
\hline Categories & Codes & Participants \\
\hline $\begin{array}{l}\text { Outcomes } \\
\text { of integrated }\end{array}$ & The potential problems with integrated STEM education \\
STEM & Teacher-based problems & T3, T5, T6, T7 \\
education into & Technical deficiencies & T5 \\
the science & Economic problems & T6 \\
curriculum & Time problems & T9 \\
& Applicability & T5 \\
& Effects of integrated STEM education \\
& Effects to teachers & \\
& Positive effects & T10, T2, T3, T4, T5, T6, T7, \\
& & T8, T9 \\
& Effects to science education & \\
& Positive effects & T1, T10, T2, T8, T9, T5, T6 \\
& Negative effects & T5 \\
& Effects to students & T1, T2, T3, T6, T7, T8, T9 \\
& Positive effects & T2, T5 \\
\hline
\end{tabular}

STEM: Science, technology, engineering, and mathematics

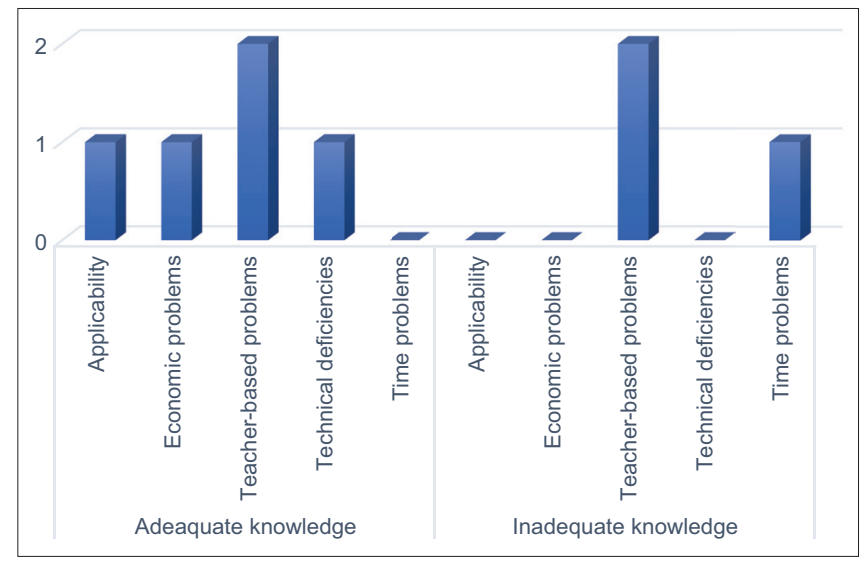

Figure 3: Teachers' beliefs regarding potential problems in science, technology, engineering, and mathematics (STEM) education integration in terms of their STEM knowledge innovations are made in engineering fields. Instead of teachers, who constantly repeat theoretical subjects, there would be teachers who make research, improve themselves.

T4's statement indicates that STEM education would help teachers to keep up with developing technologies and improve themselves. Similarly, T8 also emphasized on teachers' selfimprovement by stating that "I believe this will allow teachers to introduce creative ideas and improve themselves."

When teachers' beliefs regarding the effects of integrated STEM education on students were examined, it was determined that it would have positive effects on students in terms of achievement, original product, lead to thinking, use in daily life, hands-on learning, and professional development. According to the teachers, the possible negative effects of integrated STEM education on students were such as students not being ready for these implementations and some subjects would be hard to teach, since they think that not every attainment would be applicable. Teachers also think that integrated STEM education would have positive and negative effects on science education. They think it would contribute to the science education process in terms of concretization, attention, and improving higherorder thinking skills. Teachers' beliefs regarding integrated STEM education's positive effects on science education were examined in terms of having adequate and inadequate STEM education knowledge, as illustrated in Figure 4.

When Figure 4 is examined, it can be seen that teachers with adequate STEM education knowledge believed that STEM would have more positive contributions to science education than teachers with inadequate STEM education knowledge. For example, T6, who had adequate knowledge, stated that:

If students are provided with an environment where they are allowed to practice what they picture in their minds, they will love and have more interest in science. As a result, they will achieve something concrete and there will be a transformation from abstract to concrete.

T6's statement indicated that the participants believe that STEM education would contribute to science education in

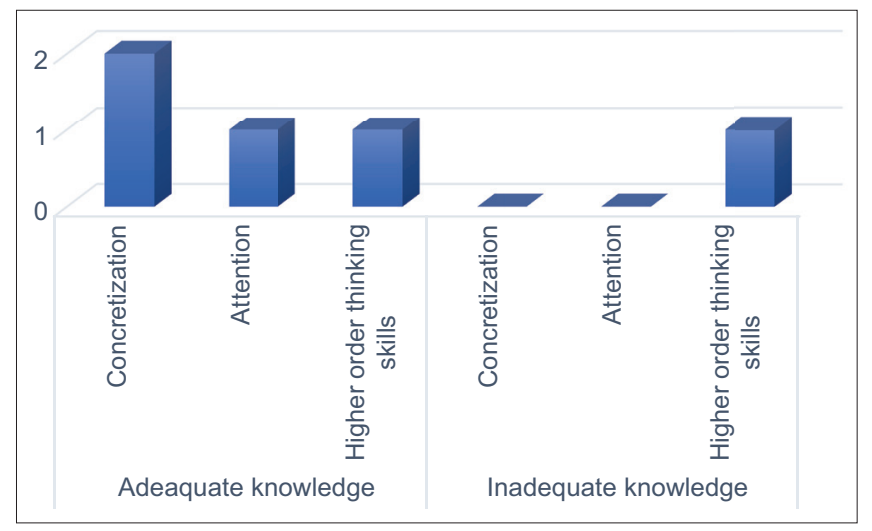

Figure 4: Teachers' beliefs regarding integrated science, technology, engineering, and mathematics (STEM) educations' positive effects on science education in terms of having adequate and inadequate STEM education knowledge 
terms of motivation, attitude, and concretization. T5 also stated that it would contribute to concretization. Another thing, T5 mentioned was her belief regarding the inapplicability of STEM education to every subject. T5 expressed her view about this situation saying "It does not look possible to teach every subject through STEM activities. Since it looks hard to combine STEM activities with the content that was prepared by Ministry of National Education, this is the negative side of the implementations."

Findings of the Analysis of the Fourth Research Question Within the framework of the third research question, teachers' suggestions regarding the implementation of integrated STEM education were determined. Based on the obtained data teachers' suggestions regarding the implementation of STEM were examined under categories of teachers, students, and STEM laboratories (Table 4).

When the suggestions of teachers were examined, it could be seen that participants stated that teachers perceived themselves to be unqualified for integrated STEM education, and they should receive training about STEM education. This training was suggested to be provided as pre-service and in-service training. T4, who argued that pre-service training should be provided by teacher training agencies, stated that teacher training programs should be regulated and suggested engineering and technology-based training. Teachers, who said that there should be in-service trainings, suggested that these trainings should take place in the form of a briefing, with activities such as conferences/symposiums and in active learning environments. Participants especially emphasized that teachers should learn by experiment. For example, T6 stated that training should not only be theoretical, rather teachers should learn through applications of these trainings. T8 emphasized the active participation of teachers by saying that

"If teachers will teach something to students in laboratories, these trainings should have an enforcement and a consequence on behalf of teachers and to learn, teachers should touch the materials, they should be active in the process."

Only T1 made suggestions for students. T1's suggestion about encouraging students to take part in the education process voluntarily is as follows:

\begin{tabular}{lc}
\hline $\begin{array}{l}\text { Table 4: Suggestions for integrated STEM education into } \\
\text { the science curriculum }\end{array}$ \\
\hline Categories & Participants \\
\hline Suggestions for teachers & \\
In-service training & $\mathrm{T} 2, \mathrm{~T} 3$ \\
Briefing & $\mathrm{T} 6, \mathrm{~T} 8$ \\
Conference symposium & $\mathrm{T} 1, \mathrm{~T} 5, \mathrm{~T} 6, \mathrm{~T} 8, \mathrm{~T} 9$ \\
Active learning environments & $\mathrm{T} 4, \mathrm{~T} 10$ \\
Pre-service training & $\mathrm{T} 1$ \\
Suggestions for students & $\mathrm{T} 1, \mathrm{~T} 10, \mathrm{~T} 2, \mathrm{~T} 3, \mathrm{~T} 4, \mathrm{~T} 6, \mathrm{~T} 7, \mathrm{~T} 8, \mathrm{~T} 9$ \\
\hline Suggestions for STEM laboratories \\
\hline STEM: Science, technology, engineering, and mathematics
\end{tabular}

It does not make sense to make STEM mandatory. If students are not willing, there will be no authentic products. So it should primarily be on a volunteer basis. If the student is volunteered big projects about his/her future career might be developed. So the students might go beyond his/her imagination.

T1's statement indicated the importance of voluntary participation. When teachers' suggestions about STEM laboratories were examined, it could be seen their emphasize on the fact that STEM education was interdisciplinary. Some teachers also think that crowded classrooms were not suitable for STEM laboratories. Thus, they suggested an environment where students could work in smaller groups. Most of the teachers especially underlined that the students should feel comfortable. For example, T6 offered the suggestions regarding the design of STEM laboratories as follows:

To begin with, STEM laboratories should be an environment where students can study comfortably. It should be an environment where they can store the products. It should be equipped for individual and group work. It must have adequate equipment. Because if the students cannot bring what they imagined to bear, they might lose their motivation.

In her statement, T6 mentioned the necessity to eliminate the technical shortcomings, in addition to the necessity to create a comfortable study environment for the students. The statement of T3, which put an emphasis on laboratories being designed as student-centered, was as follows "It should be designed rather based on engineering. It should be an environment where students can be free. It should be designed in a way that students can reveal their authentic ideas."

\section{DISCUSSION, CONCLUSIONS, AND IMPLICATIONS}

In this study, teachers' STEM education knowledge was examined under these categories; STEM concept knowledge, curriculum knowledge, and STEM implementation knowledge. It was also determined that teachers, who perceived themselves to have insufficient STEM knowledge, had heard about the concept of STEM but they could not explain it. Teachers, who could make adequate explanations, emphasized that STEM was an interdisciplinary approach; this supports studies in the literature (e.g. Bakırc1 and Kutlu, 2018; English, 2017; Lesseig et al., 2017; Roberts, 2012; Uğraş, 2017). Teachers also mentioned the disciplines that STEM includes the integration of these disciplines as in the Bakırc1 and Kutlu (2018)'s study. In this case, it could be said that teachers who were evaluated as having adequate knowledge explained the concept of STEM accurately. In their study, Eroğlu and Bektaș (2016) also determined that teachers try to explain the concept of STEM by associating it at least with one of disciplines of engineering, mathematics or technology. They also found out that teachers think that there is a relationship between science classes and technology, engineering, and mathematics. Teachers considering integrated STEM education as a production process, was 
consistent with the explanations regarding engineering skills in the science curriculum by MoNE (2017). In their study, Bakırc1 and Kutlu (2018) stated that teachers explained STEM approach by associating them with the concepts of problem solving, research-based learning, product presentation, and student-centered activity. This situation might be an indicator of teachers' explanations in accordance with STEM education program. Examining teachers' statements regarding integrated STEM education, it can be seen that teachers made no comment about these implementations and most of them have inadequate knowledge. Teachers consider STEM classes as regular science laboratories, where teachers make demonstrations and experiments. They also believed that there would be problems regarding equipment and time during the implementation process. This finding is similar to Eroğlu and Bektaş's (2016) findings that is teachers claiming that they wanted to implement STEM-based lectures but they were having problems regarding equipment and time. Similarly, Straw et al. (2012) mentioned the problems regarding time and equipment during the process of integrated STEM education in the science education. When the literature was analyzed, there are problems related to material inadequacy, lack of equipment and technology, lack of laboratory materials, time problems, and incompatibility with the curriculum in the process of integrated STEM education (Bakırcı and Kutlu, 2018; Bölükbaşı and Görgülü, 2019; İnançlı and Timur, 2018; Özcan and Koştur, 2018).

Another dimension that was addressed in the study was the determination of teachers' beliefs that would be believed to affect STEM education implementation. First, teachers' beliefs regarding self-efficacy about implementing integrated STEM education in their own classes were examined. Beliefs regarding self-efficacy are especially important for success in STEM education (Zeldin et al., 2008). It was determined that most of the teachers considered themselves inadequately prepared for integrated STEM education. When the relationship between sufficient STEM knowledge and belief of self-efficacy was examined, it was found out that only two teachers with adequate knowledge considered themselves as qualified. The reason for teachers with adequate knowledge to feel unqualified might be the lack of information about the implementation of integrated STEM education. This situation was explained by the fact that the teachers who considered themselves as inadequately prepared did not receive any training about this subject and they also mentioned that they felt unqualified. The study of Nadelson et al. (2013) also supports this view with their findings regarding vocational development programs about STEM affecting teachers' confidence, qualifications, and attitudes toward engineering in a positive way.

In our study, when teachers' beliefs regarding the problems that might be encountered during an integrated STEM education process were examined, it was found out that the emphasis was especially on teacher based problems. It was also found out that teachers with sufficient STEM knowledge believed that more problems based on teachers might be encountered. This finding is supported by the studies in the literature, which mention teacher based problems during STEM implementations (Bakırc1 and Kutlu, 2018; Cavlazoglu and Stuessy, 2017; Hutchison, 2012; İnançlı and Timur, 2018; Özcan and Koştur, 2018; Siew et al., 2015). Hutchison (2012) talked about the insufficient number of certified and qualified teachers for providing STEM education in American middle and high schools. In a similar way, qualified teachers will be needed to provide STEM education when the implementation begins in Turkey. In studies conducted in Turkey, it is especially determined that problems arising from the lack of knowledge of teachers in the integrated STEM education (Bakırc1 and Kutlu, 2018; İnançlı and Timur, 2018; Özcan and Koştur, 2018). Another problem that was encountered during integrated STEM education was teachers with individual field specialties in STEM content fields having limited experience in integrating STEM education (Cavlazoglu and Stuessy, 2017). In this study, teachers mentioned their lack of experience regarding integrated STEM education. They also thought that the lack of the implementation of STEM education would affect integrated STEM education in a negative way and teachers should be trained on this subject. In this study, Siew et al. (2015) stated that teachers, who used integrated STEM education in their classes, would have problems due to the lack of STEM training. In line with the views of the teachers, this study suggests inservice STEM education training such as briefings, conferencesymposium, active learning environments, to overcome this problem. In the study of Uğraş (2017), like this study, the teachers stated that in-service training, adding courses at the undergraduate level, establishing STEM centers, and attending STEM-themed congresses and workshops were necessary to implement the STEM education approach successfully. National Research Council (2007) and NSTA (2002) mentioned the necessity for constant STEM education for teachers, to overcome these problems. This training can be realized by creating environments for questioning, authentic applications and active learning for improving teachers' ongoing vocational development (National Research Council, 2000). In this study, teachers put an emphasis on training being provided by creating learning environments for teachers, where they could actively participate in the training. In this study, Allen et al. (2016) argued that teacher educators and professional development providers need methods for supporting STEM teachers while they reflect critically on and also implement constructivist paradigm and inquiry-based STEM education. The study conducted by Cavlazoglu and Stuessy (2017) provided convincing evidence that teachers' workshop, which teachers participate actively, was useful in terms of field-based knowledge. The results provided in the STEM education report showed that most of the teachers in Turkey think that STEM should start to be a part of the curriculum that is provided in the faculties of education and science and mathematics teachers should receive in-service training (MoNE, 2016).

Some teachers in this study suggested pre-service STEM training. In this study, Daugherty et al. (2014) argued that future teachers, who receive training that was integrated 
with STEM content and pedagogy, would provide classes with rich content, gain self-esteem, and be more willing to provide STEM content to their students in the future. Thus, future directives should include vocational development, within which integrated STEM education and applicable frameworks for related curriculum resources are available (Moore et al., 2014; Nadelson et al., 2012 is in English, 2017). In their research, Karakaya et al. (2018) examined the awareness of science teachers of STEM approach according to their in-service/course/seminar status. The results of their research revealed that the awareness of science teachers toward STEM approach was significantly different in favor of the teachers who took in-service/course/seminars. Based on the acquired data, STEM and STEM-based class activities should be increased and the content/scope of the training should be widened (Eroğlu and Bektaş, 2016). In addition to the teacherbased problems, teachers also talked about problems regarding the applicability, finances, and time.

In the research, teachers' perceptions regarding the effects of integrated STEM education on teachers, students, and science education were determined based on the views of the teachers. Teachers mostly believe that integrated STEM education would have positive effects. Regarding the effects of integrated STEM education on teachers, it could be seen that they believed that the effects would be positive for both vocational and individual development of the teachers. In their study, Siew et al. (2015) also stated that STEM education contributed to teachers' vocational developments. Teachers also believed that integrated STEM education had positive effects on students in terms of achievement, original product, lead to thinking, use in daily life, hands-on learning, and professional development. Based on the views of the science teachers Eroğlu and Bektaş (2016) found that STEM and STEM-based activities had positive effects on students. Their results were similar to the results of this study. The positive effects stated in their study were increased motivation and attention, improved scientific process skills and psychomotor skills, improved creativity and productivity, gaining a positive point of view, and spending productive time during science classes. Similarly, Weber et al. (2013) found that students took critical and active parts in STEM education environments and this had positive effects on students. Based on teacher's views, Siew et al. (2015) stated that STEM workshops provided fun, hands-on classes to the students. They also emphasized that this approach increased the students' attention and motivation for science classes. In other studies in the literature, it was stated that STEM education improved students' scientific process skills, problem solving skills, and their interest and motivation toward the course in line with the opinions of teachers (Bakırc1 and Kutlu, 2018; Bölükbaşı and Görgülü, 2019; Uğraş, 2017). Teachers interviewed in this study believed that integrated STEM education would have positive effects on science education. It is believed that these positive effects will be materialization, attention, and advanced thinking skills.

To sum up, it is believed that teachers' STEM knowledge and perceptions have an effect on their perceived ability to integrated STEM education implementations. Nadelson et al. (2013) argued that teachers' inadequate knowledge, confidence, and qualifications prevent students from learning STEM. Since this curriculum is not yet implemented in Turkey, the data about teachers' knowledge and beliefs were collected through interviews with teachers. With the beginning of the implementation of the curriculum, a future study might examine the ways teachers' knowledge and perceptions are affected by the implementation using in-class observations. Based on the obtained data and by taking the contributions of integrated STEM education to science education, teachers, and students into consideration; it can be suggested that teachers as the implementers of the curriculum, to enable an efficient integrated STEM education, should receive training and student-based STEM laboratories should be designed. To improve their qualifications, it can also be suggested that teachers receive in-service training, within which they will actively take part. During the pre-service period, teacher training programs should be updated by integrating STEM education into the curriculums.

\section{REFERENCES}

Allen, M., Webb, A.W., \& Matthews, C.E. (2016). Adaptive teaching in STEM: Characteristics for effectiveness. Theory Into Practice, 55(3), 217-224.

Bakırcı, H., \& Kutlu, E. (2018). Fen bilimleri öğretmenlerinin FeTeMM yaklaşımı hakkındaki görüşlerinin belirlenmesi [Determining the views of science teachers about STEM approach]. Türk Bilgisayar ve Matematik Eğitimi Dergisi [Turkish Journal of Computer and Mathematics Education], 9(2), 367-389.

Bölükbaşı, G., \& Görgülü, A.A. (2019). Fen bilimleri öğretmenlerinin FeTeMM eğitimi ve etkinliklerine yönelik görüşleri [science teachers' views on STEM education and activities]. Academic Perspective Procedia, 2(1), 47-56.

Cavlazoglu, B., \& Stuessy, C. (2017). Changes in science teachers' conceptions and connections of STEM concepts and earthquake engineering. The Journal of Educational Research, 110(3), 239-254.

Clewell, B.C., de Cohen, C.C., Tsui, L., Forcier, K., Gao, E., Young, N., \& West, C. (2005). Final Report on the Evaluation of the National Science Foundation Louis Stokes Alliances for Minority Participation Program. Washington, DC: Program for Evaluation and Equity Research, The Urban Institute.

Corbin, J., \& Strauss, A.L. (2015). Basics of Qualitative Research: Techniques and Procedures for Developing Grounded Theory. $4^{\text {th }}$ ed. London: Sage.

Corbin, J.M., \& Strauss, A. (1990). Grounded theory research: Procedures, canons, and evaluative criteria. Qualitative Sociology, 13(1), 3-21.

Corlu, M.S., Capraro, R.M., \& Capraro, M.M. (2014). Introducing STEM education: Implications for educating our teachers for the age of innovation. Education and Science, 39(171), 74-85.

Countryman, J., \& Olmsted, D. (2012). The Technovation Challenge: Increasing Girls' Interest in Computer Science, Technology Careers, and Entrepreneurship. Vol. 42. In WEPAN Annual Conference. Columbus, $\mathrm{OH}$.

Creswell, J.W. (2007). Qualitative Inquiry and Research Design: Choosing among Five Approaches $2^{\text {nd }}$ ed. Thousand Oaks, CA: Sage.

Creswell, J.W. (2009). Research Design: Qualitative, Quantitative, and Mixed Methods Approaches $3^{\text {rd }}$ ed. Thousand Oaks: Sage Publications.

Creswell, J.W., \& Creswell, J.D. (2002). Research Design: Qualitative, Quantitative, and Mixed Methods Approaches. Thousand Oaks, CA: Sage Publications.

Cunningham, C.M., Knight, M.T., Carlsen, W.S., \& Kelly, G. (2007) Integrating engineering in middle and high school classrooms. International Journal of Engineering Education, 23(1), 3-8. 
Dani, D.E., Hartman, S.L., \& Helfrich, S.R. (2017). Learning to teach science: Elementary teacher candidates facilitate informal STEM events. The New Educator, 14, 363-380.

Daugherty, M.K. (2013). The prospect of an "A" in STEM education. Journal of STEM Education: Innovations and Research, 14(2), 10-15.

Daugherty, M.K., Carter, V., \& Swagerty, L. (2014). Elementary STEM education: The future for technology and engineering education? Journal of STEM Teacher Education, 49(1), 45-55.

Denzin, N.K., \& Lincoln, Y.S., (Eds.). (2005). The Sage Handbook of Qualitative Research. $3^{\text {rd }}$ ed. Thousand Oaks, CA: Sage.

English, L.D. (2017). Advancing elementary and middle school STEM education. International Journal of Science and Mathematics Education, $15(1), 5-24$

Epstein, D., \& Miller, R.T. (2011). Slow off the mark: Elementary school teachers and the crisis in STEM education. Education Digest, 77(1), 4-10.

Eroğlu, S., \& Bektaş, O. (2016). STEM eğitimi almış fen bilimleri öğretmenlerinin stem temelli ders etkinlikleri hakkındaki görüşleri [Ideas of Science Teachers took STEM Education about STEM based Activities]. Eğitimde Nitel Araştırmalar Dergisi-Journal of Qualitative Research in Education, 4(3), 43-67.

Fennema, E., \& Franke, M.L. (1992). Teachers' knowledge and its impact. In: Grouws, D.A., (Ed.), Handbook of Research on Mathematics Teaching and Learning. New York: Macmillan. pp. 147-164.

Fioriello, P. (2014). Understanding the Basics of STEM Education. Available from: http://www.drpfconsults.com/understanding-the-basics-of-stemeducation.

Fore, G.A., Feldhaus, C.R., Sorge, B.H., Agarwal, M., \& Varahramyan, K. (2015). Learning at the nano-level: Accounting for complexity in the internalization of secondary STEM teacher professional development. Teaching and Teacher Education, 51, 101-112.

Galosy, J.A., \& Gillespie, N.M. (2013). Community, inquiry, leadership: Exploring early career opportunities that support STEM teacher growth and sustainability. The Clearing House: A Journal of Educational Strategies, Issues and Ideas, 86(6), 207-215.

Goldhaber, D., Gratz, T., \& Theobald, R. (2016). What's in a Teacher Test? Assessing the Relationship Between Teacher Licensure Test Scores and Student Secondary STEM Achievement. Available from: https:// www.caldercenter.org/publications/what $\%$ E2\% $\% 0 \% 99$ s-teacher-testassessing-relationship-between-teacher-licensure-test-scores-and. [Last retrieved on 2020 Feb 04].

Hutchison, L.F. (2012). Addressing the STEM teacher shortage in American schools: Ways to recruit and retain effective STEM teachers. Action in Teacher Education, 34(5-6), 541-550.

İnançl1, E., \& Timur, B. (2018). Fen bilimleri öğretmen ve öğretmen adaylarının STEM eğitimi hakkındaki görüşleri [Views of science teachers and prospective teachers on STEM education]. Uluslararasl Bilim ve Eğitim Dergisi [International Journal of Science and Education], 1(1), 48-68.

Kahan, J.A., Cooper, D.A., \& Bethea, K.A. (2003). The role of mathematics teachers' content knowledge in their teaching: A framework for research applied to a study of student teachers. Journal of Mathematics Teacher Education, 6(3), 223-252.

Karakaya, F., Ayçin, Ü.N.A., Çimen, O., \& Yılmaz, M. (2018). Fen bilimleri öğretmenlerinin STEM yaklaşimina yönelik farkindaliklari [awareness of science teachers towards STEM approach]. Eğitim ve Toplum Araştırmaları Dergisi [Journal of Education and Community Research], 5(1), 124-138.

Kim, C., Kim, D., Yuan, J., Hill, R.B., Doshi, P., \& Thai, C.N. (2015). Robotics to promote elementary education pre-service teachers' STEM engagement, learning, and teaching. Computers and Education, 91, 14-31.

Lawrenz, F., Gravemeijer, K., \& Stephan, M. (2017). Introdcution to this special issue. International Journal of Science and Mathematics Education, 15 Supp11), 1-4.

Lederman, N.G. (1999). Teachers' understanding of the nature of science and classroom practice: Factors that facilitate or impede the relationship. Journal of Research in Science Teaching, 36(8), 916-929.

Lesseig, K., Slavit, D., \& Nelson, T.H. (2017). Jumping on the STEM bandwagon: How middle grades students and teachers can benefit from
STEM experiences. Middle School Journal, 48(3), 15-24.

McDonald, C.V. (2016). STEM Education: A review of the contribution of the disciplines of science, technology, engineering and mathematics. Science Education International, 27(4), 530-569.

Merriam, S.B. (1998). Qualitative Research and Case Study Applications in Education. San Francisco: Jossey Bass.

Ministry of National Education (MoNE). (2013). Elemantary School (Primary and Secondary) Science Curriculum, 6- $8^{\text {th }}$ Grades. Ankara: Ministry of National Education.

Ministry of National Education (MoNE). (2016). STEM Education Report. Ankara. Available from: http://www.yegitek.meb.gov.tr/STEM_Egitim i Raporu.pdf. [Last retrieved on $2020 \mathrm{Feb}$ 04].

Ministry of National Education (MoNE). (2017). Elemantary School (Primary and Secondary) Science Curriculum, 3-8th Grades. Ankara. Available from: http://www.mufredat.meb.gov.tr/ProgramDetay. aspx?PID=325. [Last retrieved on $2020 \mathrm{Feb}$ 04].

Moore, T., Stohlmann, M., Wang, H., Tank, K., Glancy, A., \& Roehrig, G. (2014). Implementation and integration of engineering in K-12 STEM education. In: Purzer, S., Strobel, J., \& Cardella, M., (Eds.), Engineering in Pre-College Settings: Synthesizing Research, Policy, and Practices. West Lafayette: Purdue University Press. pp. 35-60.

Nadelson, L.S., Callahan, J., Pyke, P., Hay, A., Dance, M., \& Pfiester, J. (2013). Teacher STEM perception and preparation: Inquiry-based STEM professional development for elementary teachers. The Journal of Educational Research, 106(2), 157-168.

National Research Council. (2000). Inquiry and the National Science Education Standards: A Guide for Teaching and Learning. Washington, DC: National Academy Press.

National Research Council. (2007). Taking Science to School: Learning and Teaching Science in Grades K-8. Washington, DC: National Academy Press.

National Research Council. (2011). Successful K-12 STEM Education: Identifying Effective Approaches in Science, Technology, Engineering, and Mathematics. Washington, D.C: National Academies Press.

National Science Teachers Association. (2002). An NSTA Position Statement: Elementary School Science. Arlington, VA: Author.

Özcan, H., \& Koştur, H.İ. (2018). Fen bilimleri dersi öğretmenlerinin STEM eğitimine yönelik görüşleri [Science teachers' views on STEM education]. Özgün Araştırma Dergisi [Original Research Journal], 8(4), 364-373.

Patton, M.Q. (1999). Enhancing the quality and credibility of qualitative analysis. Health Services Research, 34(5), 1189-1209.

Pryor, B.W., Pryor, C.R., \& Kang, R. (2016). Teachers' thoughts on integrating STEM into social studies instruction: Beliefs, attitudes, and behavioral decisions. The Journal of Social Studies Research, 40(2), 123-136.

Richardson, V., Anders, P., Tidwell, D., \& Lloyd, C. (1991). The relationship between teachers' beliefs and practices in reading comprehension instruction. American Educational Research Journal, 28(3), 559-586.

Ring, E.A., Dare, E.A., Crotty, E.A., \& Roehrig, G.H. (2017). The evolution of teacher conceptions of STEM education throughout an intensive professional development experience. Journal of Science Teacher Education, 28(5), 444-467.

Roberts, A. (2012). A justification for STEM education. Technology and Engineering Teacher, 71(8), 1-4.

Shulman, L. (1987). Knowledge and teaching: Foundations of the new reform. Harvard Educational Review, 57(1), 1-23.

Siew, N.M., Amir, N., \& Chong, C.L. (2015). The perceptions of pre-service and in-service teachers regarding a project-based STEM approach to teaching science. SpringerPlus, 4(8), 1-20.

Staub, F.C., \& Stern, E. (2002). The nature of teachers' pedagogical content beliefs matters for students' achievement gains: Quasi-experimental evidence from elementary mathematics. Journal of Educational Psychology, 94(2), 344-355.

Strauss, A., \& Corbin, J. (1998). Basics of Qualitative Research: Techniques and Procedures for Developing Grounded Theory. $2^{\text {nd }}$ ed. Thousand Oaks, CA: Sage Publications, Inc.

Straw, S., MacLeod, S., \& Hart, R. (2012). Evaluation of the Wellcome Trust Camden STEM Initiative. Slough: NFER.

Thompson, A.G. (1992). Teachers' beliefs and conceptions: A synthesis 
of the research. In: Grouws, D.A., (Ed.), Handbook of Research on Mathematics Teaching and Learning. New York: Macmillan Publishing Company. pp. 127-146.

Turkish Academy of Sciences. (2010). Bilim Raporu 2009 [Science Report 2009]. Ankara, Turkey.

Uğraş, M. (2017). Okul öncesi öğretmenlerinin STEM uygulamalarına yönelik görüşleri [Preschool teachers' views about STEM applications]. The Journal of New Trends in Educational Science, 1(1), 39-54.

Weber, E., Fox, S., Levings, S.B., \& Bouwma-Gearhart, J. (2013). Teachers' conceptualizations of integrated STEM. Acad Exchange, 17(3), 47-53.

Yıldırım, A., \& Şimşek, H. (2011). Sosyal Bilimlerde Nitel Araştırma
Yöntemleri [Qualitative Research Methods in Social Sciences]. $8^{\text {th }}$ ed. Ankara: Seçkin Publications.

Yin, R. (2014). Case Study Research: Design and Methods. $5^{\text {th }}$ ed.). Thousand Oaks, CA: Sage.

You, H.S. (2017). Why teach science with an interdisciplinary approach: History, trends, and conceptual frameworks. Journal of Education and Learning, 6(4), 66-77.

Zeldin, A.L., Britner, S.L., \& Pajares, F. (2008). A comparative study of the self-efficacy beliefs of successful men and women in mathematics, science, and technology careers. Journal of Research in Science Teaching, 45(9), 1036-1058. 